\section{Genetic Diversity of Hazelnut (Corylus avellana L.) Germplasm in Northeastern Spain}

\author{
Paolo Boccacci ${ }^{1}$ and Roberto Botta ${ }^{1}$ \\ Dipartimento di Colture Arboree, Università degli Studi di Torino, Via \\ Leonardo da Vinci 44, 10095 Grugliasco (Torino), Italy
}

\begin{abstract}
Mercè Rovira
Institut de Recerca i Tecnologia Agroalimentàries (IRTA), Arboricultura Mediterràia, Centre Mas de Bover, Ctra. Reus-El Morell, km 3.8, 43120 Constanti' (Tarragona), Spain
\end{abstract}

Additional index words. filbert, genetic relationships, microsatellite, simple sequence repeat, SSR markers

\begin{abstract}
In Spain, hazelnut is mainly cultivated in Catalonia, a region in the northeast. The province of Tarragona accounts for $88 \%$ of the total Spanish area planted to hazelnut. Almost $80 \%$ of the production in Tarragona is of the local cultivar Negret, with others cultivated to a lesser extent. Minor cultivars are only sporadically present in older orchards, farm yards and gardens, and have been collected for preservation. In this work, 16 SSR markers were used to fingerprint 18 minor hazelnut cultivars from northeastern Spain. Their microsatellite profiles were combined with those of 15 Spanish cultivars characterized in a previous work, and used to study the genetic diversity in $\mathbf{3 3}$ genotypes including local Spanish germplasm. The SSR analysis allowed development of unique profiles of each of the 18 cultivars, and no new case of synonymy was detected. A high level of genetic diversity (mean $H_{e}=0.7$ ) was observed in 33 genotypes, although a high number of them showed a close genetic relationship. The dendrogram generated by UPGMA cluster analysis placed the 33 accessions into nine main groups, related to their putative pedigrees or geographical area of cultivation. All investigated Negret-type cultivars were found to be distinct from Negret, and only a few cultivars within this germplasm appeared to be seedlings of Negret. The results will be useful in the conservation of hazelnut germplasm and in the selection of parents for use in breeding.
\end{abstract}

The European hazelnut (Corylus avellana L.) is one of the world's major nut crops. Its geographic distribution extends from the Mediterranean coast of North Africa northward to the British Isles and the Scandinavian Peninsula, and eastward to the Ural Mountains of Russia, the Caucasus Mountains, Iran, and Lebanon (Thompson et al., 1996). Total worldwide hazelnut production is fifth after that of cashew (Anacardium occidentale L.), almond [Prunus dulcis (Miller) D.A. Webb], walnut (Juglans regia L.), and chestnut (Castanea spp.). Turkey has long been the leading producer and exporter of hazelnuts, accounting for about $71 \%$ of world production. Italy is second with over $13 \%$,

Received for publication 11 Oct. 2007. Accepted for publication $24 \mathrm{Jan} .2008$.

The authors are grateful to Prof. Giovanni Me (Dipartimento di Colture Arboree, Torino, Italy) for his generous collaboration and Prof. Shawn A. Mehlenbacher (Oregon State University, Corvallis, OR) for reviewing the manuscript. The research was funded by Regione Piemonte Administration (Italy), INIA and MAPYA (Spain), and by the European Union project SAFENUT (AGRI GEN RES 068).

${ }^{1}$ To whom reprint requests should be addressed; e-mail roberto.botta@unito.it., paolo.boccacci@ unito.it the United States third with $4.1 \%$, and Spain fourth with $2.8 \%$. Azerbaijan, Iran, Georgia, China, France, and Greece are other important producers (FAOSTAT, 2007).

In Spain, hazelnut is mainly cultivated in Catalonia, a region in the northeast. The province of Tarragona accounts for $88 \%$ of the total Spanish area planted to hazelnut (Fig. 1). Minor hazelnut-growing areas include Castellón, Asturias, País Vasco, Aragón, and Navarra. Orchards in Tarragona province have been classified into two topographic groups. The first group is of orchards of the inland mountain ranges of the province ("Priorat-Prades"), located on hilly slopes and characterized by a low level of mechanization and low nut yield $\left(500-800 \mathrm{~kg} \cdot \mathrm{ha}^{-1}\right)$. The second group is of orchards in flat areas of the region called "Camp de Tarragona" located near the Mediterranean coast that use modern mechanized techniques and show high nut yield $\left(2,000-2,500 \mathrm{~kg} \cdot \mathrm{ha}^{-1}\right)$. Most commercial production is from this second area (Tous, 2005). Almost $80 \%$ of Tarragona's production is of the native cultivar Negret. 'Negret' and 'Pauetet' are sold as the commercial type "negreta" that receives the best prices on the national markets. Other Spanish cultivars (Grifoll, Gironell, Morell, Culplà, Ribet, and Trenet) are cultivated to a lesser extent. A few Italian cultivars (i.e., San
Giovanni, Tonda di Giffoni, and Tonda Gentile Romana) were introduced because of their high commercial value and have shown good adaptation to the conditions of the area.

Modern agriculture requires high yield for profitability, and consequently the number of cultivars planted has declined in recent years. To avoid loss of local germplasm, efforts have been made on a worldwide scale to collect and preserve genetic diversity. In Tarragona, the diverse local hazelnut germplasm was investigated by Tasias Valls (1975), who assigned cultivars to three groups: I) one main cultivar distributed in all hazelnut cultivation areas of the province and in regular plantations; II) cultivars that are common in some areas of the province and in regular plantations; III) minor cultivars that are not cultivated in regular plantations but are occasionally found scattered in orchards (Table 1). This germplasm has been collected and preserved in collection fields (Köksal, 2000) to preserve the genetic variability for future use (Table 2).

Traditional methods to characterize and identify hazelnut cultivars are based on phenotypic observations (Thompson et al., 1978; UPOV, 1979), but this approach is subject to environmental influences and thus requires several years to correctly define the traits of a plant. Isozyme polymorphism was proposed in the 1980s and early 1990s as an alternative and more effective method for cultivar identification and studies of genetic relationships (Ahmad et al., 1987; Rovira, 1997; Solar et al., 1997). During the last decade, DNA markers have proven to be convenient for accurately identifying cultivars due to their high discriminating power at a relatively low cost. Among the available DNA markers, microsatellite or simple sequence repeat (SSR) markers appear to be best-suited to cultivar fingerprinting. They are generally codominant, highly polymorphic, highly reproducible, and permit exchange of results among different laboratories as well as construction of an integrated database. Microsatellite markers were recently developed in $C$. avellana and evaluated in seven other Corylus species by Bassil et al. (2005a, 2005b) and Boccacci et al. (2005). On the basis of their high level of polymorphism, the most interesting loci were used to fingerprint and to identify mistakes in hazelnut accessions from several germplasm repositories (Botta et al., 2005; Gökirmak et al., 2005). Moreover, results were used to verify synonymies and parentage hypotheses and to investigate genetic relationships among cultivars grown in important (Boccacci et al., 2006; Ghanbari et al., 2005) production areas. SSR loci were also placed in a genetic map, and some of them were found linked to a dominant allele for resistance to eastern filbert blight caused by Anisogramma anomala (Peck) E. Müller (Mehlenbacher et al., 2006).

In the present work, 18 minor hazelnut cultivars from northeastern Spain were DNAtyped using microsatellite markers. Their SSR profiles were combined with those of 15 Spanish cultivars characterized by 


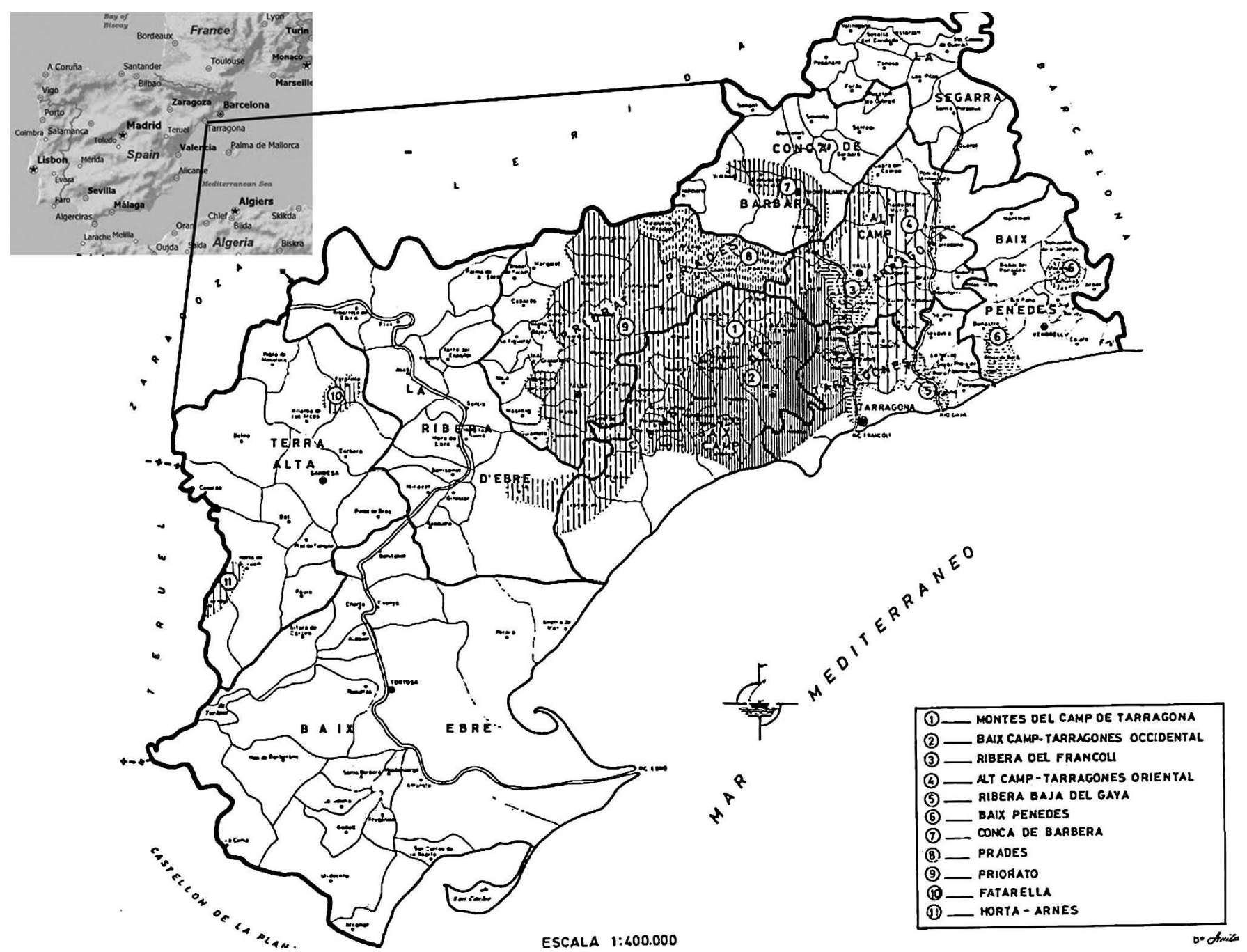

Fig. 1. Regions of Tarragona province (northeastern Spain) with hazelnut cultivation areas shown in dark (from Tasias Valls, 1975, modified).

Boccacci et al. (2006) and used to study the genetic diversity in this local germplasm, including cultivars of international interest in cultivation and breeding.

\section{Materials and methods}

Plant material and DNA extraction. Leaves were sampled from 18 accessions (Table 3) conserved in the germplasm collection field of the Institut de Recerca $i$ Tecnologia Agroalimentàries (IRTA) of Reus (Tarragona, Spain). Genomic DNA was extracted from $0.2 \mathrm{~g}$ of leaves in a Tris-EDTA$\mathrm{NaCl}$ buffer containing $0.25 \mathrm{M} \mathrm{NaCl}, 0.2 \mathrm{M}$ Tris, pH 7.6, 2.5\% PVP 40,000, $0.05 \mathrm{M}$ $\mathrm{Na}_{2}$ EDTA, and $0.1 \% \beta$-mercaptoethanol, using a modified protocol described by Thomas et al. (1993).

PCR amplification and microsatellite analysis. Sixteen SSR loci were used: CaTA114, CaT-B107, CaT-B501, CaT-B502, CaT-B503, CaT-B504, CaT-B505, CaTB507, CaT-B508, СaT-B509, СaT-B511, CaT-C001 and CaT-C504 (Boccacci et al., 2005) and $\mathrm{CaC}-\mathrm{A} 102$, CaC-B020, and $\mathrm{CaC}-$ B028 (Bassil et al., 2005a). PCR amplification was performed in a volume of $20 \mu \mathrm{L}$ containing $50 \mathrm{ng}$ of DNA, $0.5 \mathrm{U}$ of Taq-DNA polymerase (AmpliTaq Gold, Applied Biosystems, Inc., Foster City, CA), $2 \mu \mathrm{L}$ of $10 \times$ PCR buffer (100 mm Tris-HCl, pH 8.3, 500 $\mathrm{mm} \mathrm{KCl}$ ), $2 \mathrm{~mm} \mathrm{MgCl}_{2}, 200 \mu \mathrm{M}$ dNTPs, and $0.5 \mu \mathrm{M}$ of each primer. PCR conditions were as follows: an initial denaturation step at $95{ }^{\circ} \mathrm{C}$ for 9 min followed by 26 cycles of denaturation $\left(30 \mathrm{~s}\right.$ at $\left.95{ }^{\circ} \mathrm{C}\right)$, annealing $(45 \mathrm{~s}$ at $55{ }^{\circ} \mathrm{C}$ and $50{ }^{\circ} \mathrm{C}$ for CaT-B502), and extension $\left(90 \mathrm{~s}\right.$ at $\left.72^{\circ} \mathrm{C}\right)$. The final elongation step was at $72{ }^{\circ} \mathrm{C}$ for $45 \mathrm{~min}$. The forward primers were labeled with a fluorochrome (6FAM, HEX, NED, or PET), and amplification products were analyzed using an $\mathrm{ABI}$ Prism 377 sequencer (Applied Biosystems, Inc.). Results of the run were then processed with Genescan software and allele sizes were estimated using the GeneScan-500 LIZ size standard (Applied Biosystems).

Data analysis. Genetic relationships among 18 accessions analyzed in this study and 15 Spanish cultivars characterized by Boccacci et al. (2006) using the same aforesaid methods (DNA extraction, PCR amplification, and SSR analysis), were investigated by unweighted pair group method with arithmetic mean (UPGMA) cluster analysis.
Genetic distances (1000 bootstraps) were computed as $D=[1-$ (proportion of shared alleles)] using the program Microsat (Minch, 1997). Cluster analysis was performed using the Neighbor software in the Phylip v.3.5c package (Felsenstein, 1989), and a dendrogram was constructed using the TreeView program (Page, 1996). The software Identity 1.0 (Wagner and Sefc, 1999) was used to calculate expected $\left(\mathrm{H}_{\mathrm{e}}\right)$ and observed $\left(\mathrm{H}_{\mathrm{o}}\right)$ heterozygosities.

\section{Results and Discussion}

In a previous study, Boccacci et al. (2006) characterized and investigated the genetic relationships among 78 hazelnut cultivars, including 15 from Spain, using the same 16 SSR loci used in this study. We expanded the work to include 18 additional local cultivars from Tarragona province. In this paper, data from both studies were pooled for statistical analysis and investigation of genetic relationships among the 33 cultivars and genetic diversity in the local hazelnut germplasm.

The 16 SSR loci resulted in unique genotypic profiles for all of the 18 cultivars (Table 
Table 1. Spanish hazelnut cultivars described and classified by Tasias Valls (1975).

\begin{tabular}{|c|c|c|}
\hline$\overline{\text { Classification }}$ & Cultivar name & Presumed synonym names \\
\hline Group I & Negret & \\
\hline \multirow[t]{7}{*}{ Group II } & Culplà & \\
\hline & Gironell & Constanti, Gironenca, Grossal de Constanti \\
\hline & Grifoll & Queixal de gos \\
\hline & Morell & Capellut, Flocal, Falsetana, Fort, Rojeta, \\
\hline & Pauetet & \\
\hline & Ribet & \\
\hline & Trenet & \\
\hline \multirow{23}{*}{ Group III } & Artellet & Artell nano \\
\hline & Apegalos & Artell \\
\hline & Ametllenca & \\
\hline & Castanyera & $\begin{array}{l}\text { Castanyal, Castanyenca, Cul de Madrina, Grossal; } \\
\text { Barcelona in USA; Fertile de Coutard in France }\end{array}$ \\
\hline & Closca molla & Culplà moll, Mollar \\
\hline & Gironenc & Vermellet \\
\hline & Lluenta & \\
\hline & Martorella & \\
\hline & Negret capellut & Capellut \\
\hline & Negret garrofí & Garrofina, Ralladet, Ratllada \\
\hline & Punxenc & Negret caputxí, Negret garrofi \\
\hline & Pinyolenc & Floquet \\
\hline & Planeta & Culplà d'Alforja \\
\hline & Queixal de llop & \\
\hline & Queixal de ruc & \\
\hline & Ratllada & Gironell d'Alforja \\
\hline & Ratolí & Negret ratoli \\
\hline & Ros & Ros de la Selva \\
\hline & Rosset & Falsetà, Rosset de valls \\
\hline & Sant Jaume & \\
\hline & Sant Joan & \\
\hline & Sant Pere & \\
\hline & Vimbodí & \\
\hline
\end{tabular}

3), and no new cases of synonymy were detected (Fig. 2). Cases of synonymy were previously reported by Boccacci et al. (2006). The total number of alleles was 114 , and the range for each locus was from 5 to 10 (mean: 7.1). $\mathrm{H}_{\mathrm{e}}$ ranged from 0.50 to 0.80 (mean: $0.70)$, while $\mathrm{H}_{\mathrm{o}}$ ranged from 0.57 to 1.00 (mean: 0.80). These data indicate high genetic diversity in the local germplasm, comparable to that found in the larger set of cultivars analyzed by Boccacci et al. (2006). The high level of heterozygosity is a consequence of the self-incompatibility of this species. All cultivars require pollen from other genotypes to produce nuts (Germain and Sarraquigne, 2004), with the exception of the partially self-compatible 'Tombul' and 'Montebello' (syn. 'Nocchione') (Mehlenbacher and Smith, 1991).

The dendrogram generated by UPGMA cluster analysis (Fig. 2) placed the 33 accessions into nine main groups (A to I).

The most important Spanish cultivar Negret, cultivated in regular orchards in all hazelnut cultivation areas of Tarragona, was placed adjacent to Pauetet, with which it appears to have a close relationship. The three cultivars in group I share at least one allele at each locus (Table 3 and Boccacci et al., 2006). The codominant Mendelian inheritance of SSR markers allows identification of possible parent-offspring pairs in a group of closely related cultivars. Pedigree reconstruction is also possible when two cultivars share one allele at all of the loci and may be linked by a parent-offspring relationship. 'Pauetet', also known as 'd'en Bardina', is considered an open-pollinated seedling selected and propagated from the Alcover area (Alt Camp, Fig. 1) for its good nut and kernel characteristics and productivity (Table 2). 'Vimbodí' was a seedling selected and cultivated by growers in the Vimbodí area (Conca de Barberà). 'Negret' is very common in Tarragona orchards, and

Table 2. Morphological characteristics of the hazelnut cultivars grown in Tarragona province, Spain. ${ }^{\mathrm{z}}$

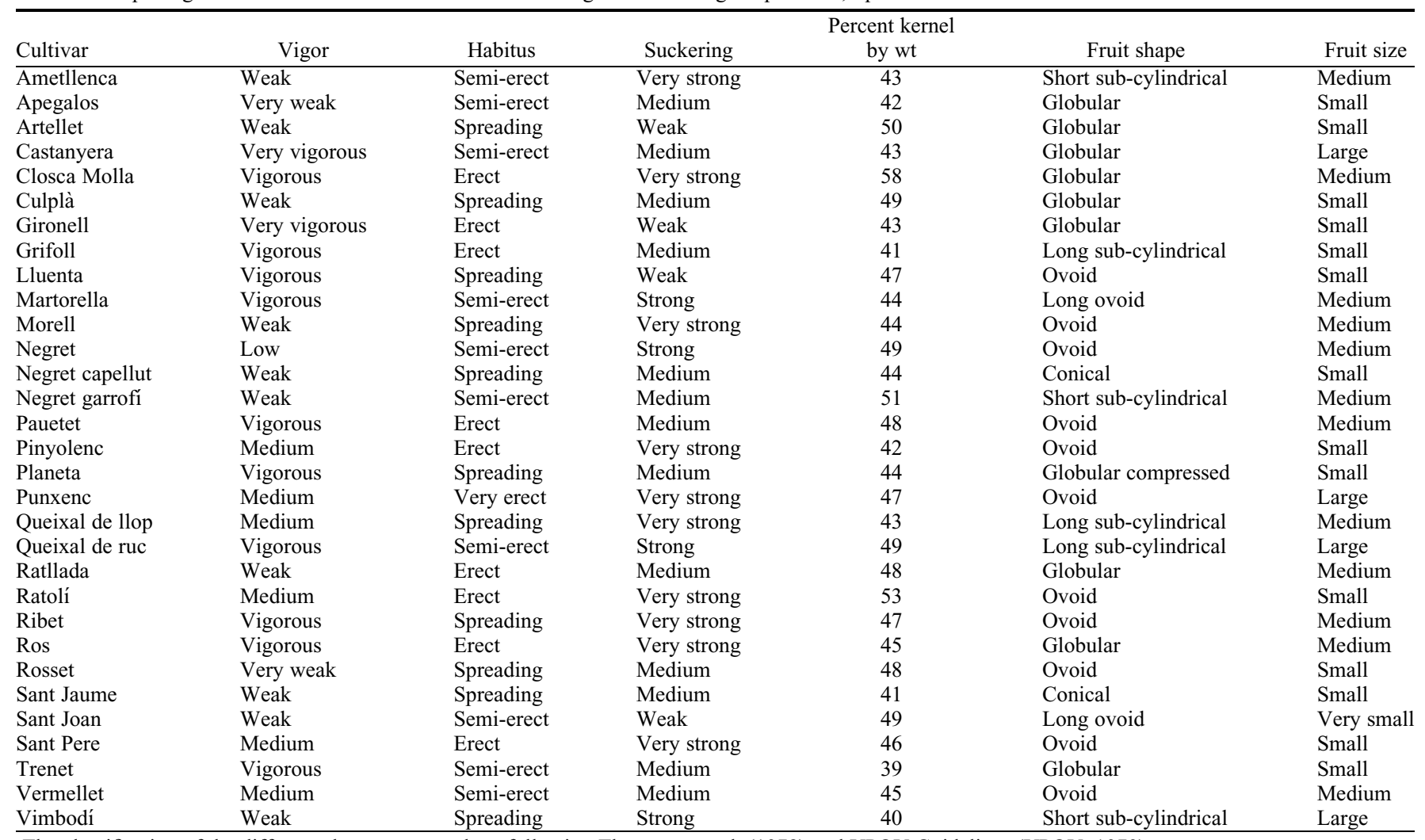

${ }^{\mathrm{z}}$ The classification of the different characters was done following Thompson et al. (1978) and UPOV Guidelines (UPOV, 1979). 


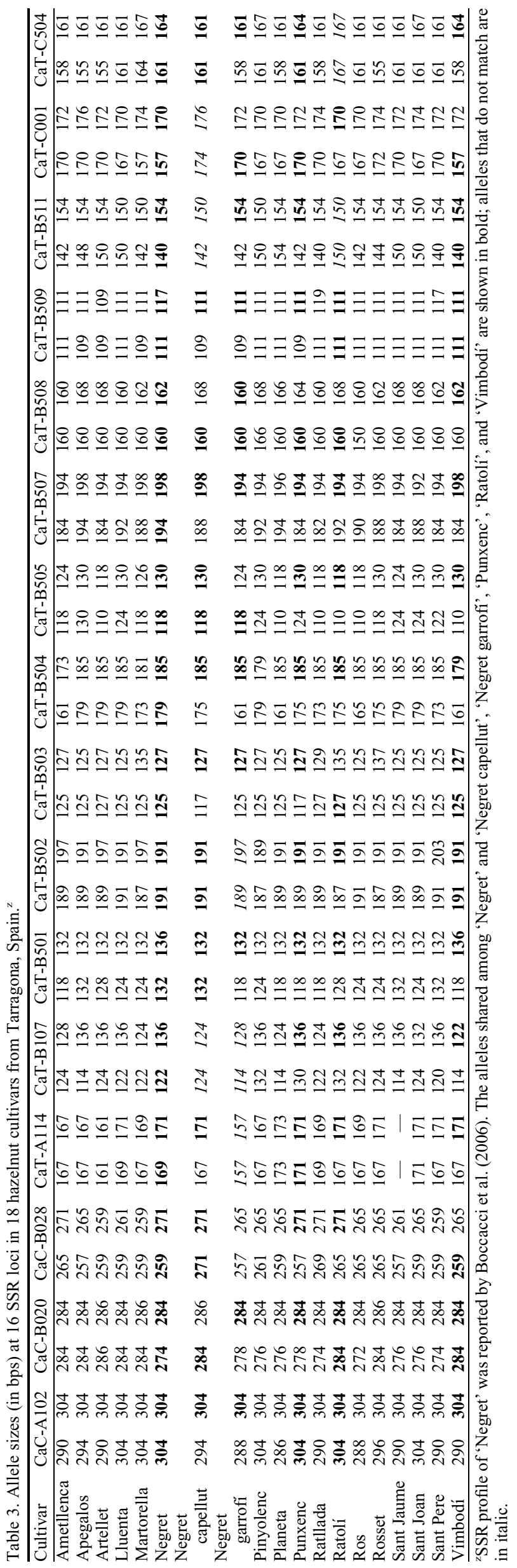

thus it is likely that Negret is a parent of both above-mentioned cultivars. The presence of a common allele at the S-locus further supports the parent-offspring relationship between 'Negret' $\left(\mathrm{S}_{10} \mathrm{~S}_{22}\right)$ and 'Pauetet' $\left(\mathrm{S}_{18} \mathrm{~S}_{22}\right)$ (Mehlenbacher, 1997).

In several of the inland mountain areas of the province, growers distinguish among 'Negret' and some morphotypes such as 'Negret caputxi' (syn. 'Punxenc' in Figuerola, Alt Camp), 'Negret capellut', 'Negret garrofi', and 'Negret ratoli' (syn. 'Ratolí') whose growth habit and nut characteristics are similar to those of 'Negret' (Table 2). Our results indicate that they are distinct cultivars, confirming the classification of Tasias Valls (1975). They show different genetic profiles from each other and from 'Negret' and were placed in separate clusters in the dendrogram. Yet their DNA profiles show that 'Negret' shares at least one allele at all loci with 'Punxenc', at 14 loci with 'Ratolí', at 13 loci with 'Negret capellut', and at 12 loci with 'Negret garrofi' (Table 3). The alleles that failed to match in 'Ratoli'' (CaTB511 and CaT-C504), 'Negret capellut' (CaT-B107, CaT-B511, and CaT-C001), and 'Negret garrofi' (CaT-A114, CaT$\mathrm{B} 107, \mathrm{CaT}-\mathrm{B} 502$, and $\mathrm{CaC}-\mathrm{B} 028$ ) show discrepancies of $2-6 \mathrm{bp}$ from the respective alleles in 'Negret', while a 12-bp discrepancy was observed in 'Negret garrofi' at locus CaT-A114 (Table 3). Short mutations are consistent with the stepwise mutation model proposed for microsatellite evolution (Jarne and Lagoda, 1996) and have already been observed between parents and progeny, such as in grape (Bowers et al., 1999; Piljac et al., 2002; Vouillamoz et al., 2003) and in hazelnut (Boccacci et al., 2006). The hypothesis of Tasias Valls (1975) that Negret is a cultivar population appears to be valid only from a commercial point of view, as the commercially sold "negreta" mixture indeed includes not only Negret and Pauetet but also these Negret-like minor cultivars. Our SSR fingerprints as well as careful observation of morphological and phenological traits indicate that Negret and these Negret-like minor cultivars are indeed different. The future of Negret-like minor cultivars is uncertain because nurseries are now propagating only Negret. The minor Negret-like cultivars persist only in older orchards and farm yards.

The cultivars 'Grifoll', 'Gironell', 'Morell', 'Culplà', 'Ribet', and 'Trenet', cultivated in regular orchards but only in some areas of the province, were placed in separate clusters. 'Grifoll' shares at least one allele at each locus with 'Martorella' (Table 3 and Boccacci et al., 2006); the two form group G. 'Martorella', a variety known only in Alforja, has a leafing out and flowering time similar to 'Grifoll' which is commonly cultivated in that region. 'Gironell' is the main cultivar in Constantí area (Tarragonès), where it is also called 'Grossal' or 'Grossal de Constantí'. It was placed in group B with the minor cultivars 'Queixal de ruc', 'Castanyera' (syn. 'Barcelona'), 'Negret garrofi', 'Ametllenca', and 'Punxenc'. Their presence 


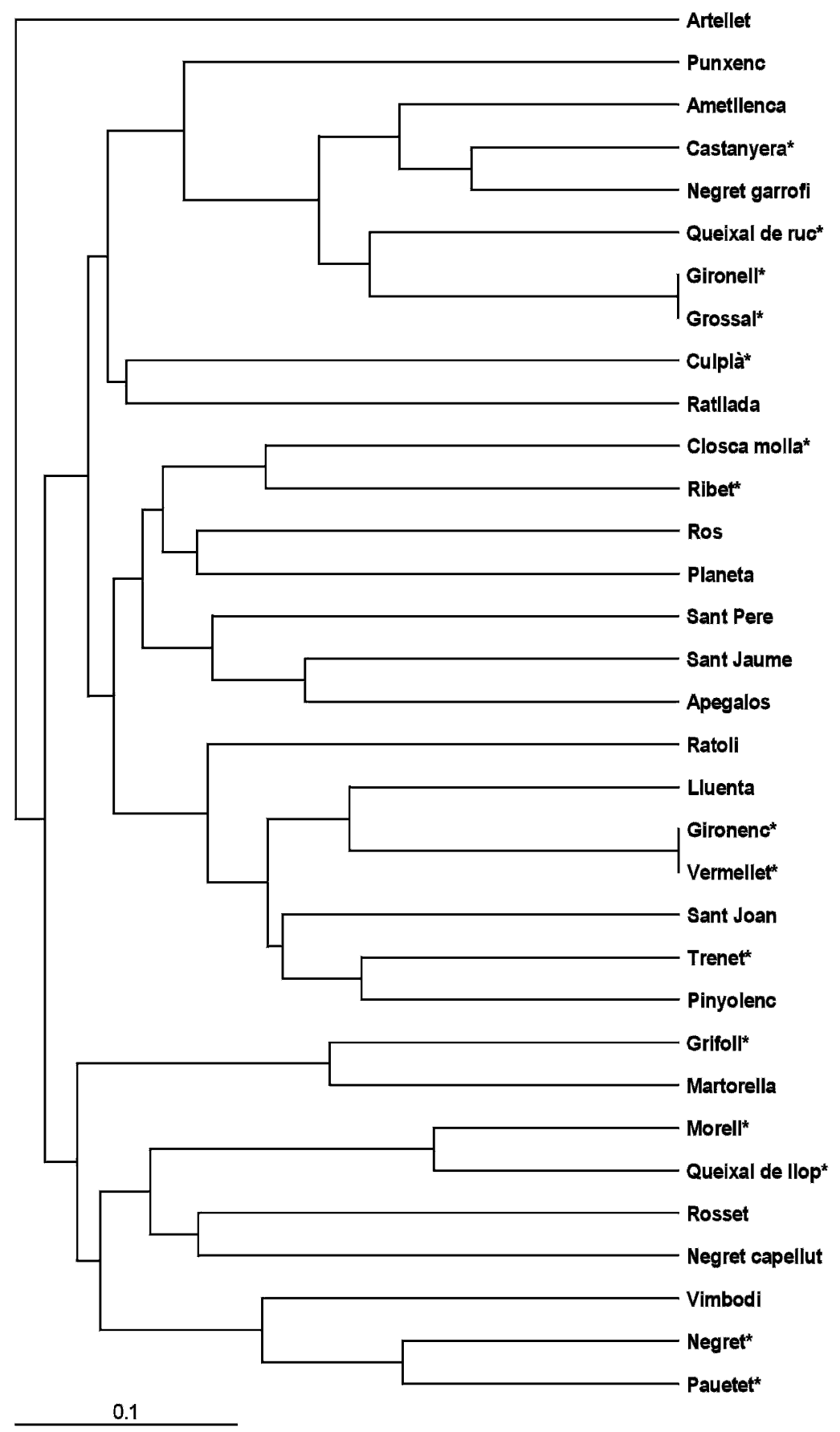

Fig. 2. UPGMA dendrogram of 33 Spanish hazelnut cultivars based on alleles at 16 SSR loci. *Cultivar analyzed by Boccacci et al. (2006) with 16 SSR loci.

is limited to some orchards in the main areas where 'Gironell' is cultivated (Alt Camp and Tarragonès) (Tasias Valls, 1975). According to the literature (Tasias Valls, 1975), 'Punxenc' is also known as 'Negret caputxí' in Figuerola (Alt Camp) and 'Negret garrofi' in Fatarella (Terra Alta); 'Negret garrofi' is considered a synonym of 'Ratllada'. Our results indicated that neither Punxenc nor Rattlada was a synonym of Negret garrofi because the three cultivars have unique genotypes (Table 3). 'Morell' and 'Culplà' are mainly cultivated in Vandellós (Baix Camp), Tivisa (La Ribera d'Ebre), and in the PrioratPrades region. 'Culplà' is also cultivated in areas as 'Morell' (Tasias Valls, 1975). These cultivars have similar morphological traits (Table 2). All of them, except for 'Rosset', have long husks that often clasp the nuts and hinder their drop at maturity. This problem is particularly evident in 'Morell' and 'Negret capellut'; for this reason 'Morell' is called 'Capellut' in Camp de Tarragona. 'Culplà' was placed in group C with 'Ratllada', a variety grown in Alforja (Baix Camp) and Villalonga (Tarragonès) (Tasias Valls, 1975). 'Ratllada' is also called 'Gironell d'Aforja', but its SSR genotype showed it not to be a synonym of 'Gironell' (Table 3 and Boccacci et al., 2006). 'Ribet', the main variety cultivated in Alforja, was placed in group D with 'Ros', 'Closca molla', and 'Planeta', which

D were found by Tasias Valls (1975) in two areas (Baix Camp and Priotat-Prades) adjacent to the cultivation center of 'Ribet'. Finally, 'Trenet' is considered to have originated as a selected seedling in Valls (Alt Camp) and is widespread in the Alt Camp E region where the other cultivars of group $\mathrm{F}$ are localized (Tasias Valls, 1975). Trenet appears to be closely related to Pinyolenc, with which it shares at least one allele at each locus, and also with Sant Joan, a cultivar native to Valls (Table 3 and Boccacci et al., 2006).

Minor cultivars not present in modern orchards but rather scattered in older TarraF gona orchards (Table 1, Group III) were placed in all clusters of the dendrogram. They appear to be closely related to the major cultivars and, in some cases, appear to have a parent-offspring relation with them. According to Tasias Valls (1975), most cultivars of Tarragona province were selected from local wild populations and from open-pollinated seedlings. Moreover, he postulated that the center of origin of these minor varieties was the mountainous area of Camp de Tarragona, where they were propagated and then spread to nearby cultivation areas. It is possible that these minor cultivars are the progenitors of the main cultivars, although the opposite case may appear more likely. Further analyses of wild and domesticated hazelnuts, including chloroplast SSRs, would improve our understanding of the origin and diffusion of the local hazelnut germplasm.

In conclusion, the present study shows a high level of genetic diversity among hazelnut cultivars from Tarragona province, although several cultivars showed a genetically close relationship. These results may prove useful in the conservation of hazelnut germplasm and in the selection of parents for use in breeding. Finally, the SSR profiles will extend the database recently developed by Boccacci et al. (2006), a useful tool to investigate genetic relationships and to identify cultivars and synonyms.

\section{Literature Cited} ctively. The different morphological characteristics of the Culplà cultivars (Table 2) and our SSR results (Table 3 ) did not confirm these suspected synonymies. 'Morell' was placed in group H with 'Queixal de llop', 'Rosset', and 'Negret capellut', all three of which are cultivated in the same

Fatarella and Horta-Arnes (Terra Alta) in Alforja, Culplà is named Planeta (syn. Culplà Priorat-Prades) growers distinguish between Culplà moll and Culplà fort, indicating with these two denominations the cultivars more commonly known as Closca molla and $\mathrm{Cul}$

Ahmad, Z., L.S. Daley, M.A. Menendez, and H.B. Lagerstedt. 1987. Characterization of filbert (Corylus) species and cultivars using gradient polyacrylamide gel electrophoresis. J. Environ. Hort. 5:11-16. 
Bassil, N.V., R. Botta, and S.A. Mehlenbacher. 2005a. Microsatellite markers in the hazelnut: isolation, characterization and cross-species amplification in Corylus. J. Amer. Soc. Hort. Sci. 130:543-549.

Bassil, N.V., R. Botta, and S.A. Mehlenbacher. 2005b. Additional microsatellites of the European hazelnut. Acta Hort. 686:105-110.

Boccacci, P., A. Akkak, N.V. Bassil, S.A. Mehlenbacher, and R. Botta. 2005. Characterization and evaluation of microsatellite loci in European hazelnut (Corylus avellana L.) and their transferability to other Corylus species. Mol. Ecol. Notes 5:934-937.

Boccacci, P., A. Akkak, and R. Botta. 2006. DNAtyping and genetic relationships among European hazelnut (Corylus avellana L.) cultivars using microsatellite markers. Genome 49:598-611.

Botta, R., A. Akkak, and P. Boccacci. 2005. DNAtyping of hazelnut: a universal methodology for describing cultivars and evaluating genetic relatedness. Acta Hort. 686:117-124.

Bowers, J.E., J.M. Boursiquot, P. This, K. Chu, H. Johansson, and C.P. Meredith. 1999. Historical genetics: the parentage of Chardonnay, Gamay, and the wine grapes of Northeastern France. Science 285:1562-1565.

FAOSTAT. 2007. Agriculture data [online]. 26 Feb. 2008. Available from: <http://faostat.fao. org/site/567/default.aspx $>$.

Felsenstein, J. 1989. PHYLIP-phylogeny inference package. Cladistics 5:164-166.

Germain, E. and J.P. Sarraquigne. 2004. Le noisetier. CTIFL, Paris, France.

Ghanbari, A., A. Akkak, P. Boccacci, A. Talaie, A. Vezvaie, and R. Botta. 2005. Characterization of hazelnut (Corylus avellana L.) cultivars using microsatellite markers. Acta Hort. 686: 111-115.

Gökirmak, T., S.A. Mehlenbacher, and N.V. Bassil. 2005. Investigation of genetic diversity among European hazelnut (Corylus avellana L.) cultivars using SSR markers. Acta Hort. 686:141-147.

Jarne, P. and P.J.L. Lagoda. 1996. Microsatellites, from molecules to populations and back. Trends Ecol. Evol. 11:424-429.

Köksal, A.Ï. 2000. Inventory of hazelnut research, germplasm and references. REU Technical Series 56. Food and Agriculture Organization of the United Nations, Rome, Italy.

Mehlenbacher, S.A. 1997. Revised dominance hierarchy for S-alleles in Corylus avellana L. Theor. Appl. Genet. 94:360-366.

Mehlenbacher, S.A. and D.C. Smith. 1991. Partial self-compatibility in 'Tombul' and 'Montebello' hazelnut. Euphytica 56:231-236.

Mehlenbacher, S.A., R.N. Brown, E.R. Nouhra, T. Gökirmak, N.V. Bassil, and T.L. Kubisiak. 2006. A genetic linkage map for hazelnut (Corylus avellana L.) based on RAPD and SSR markers. Genome 49:122-133.

Minch, E. 1997. MICROSAT, version 1.5b. 26 Feb. 2008. <http://hpgl.stanford.edu/projects/ microsat $/>$.

Page, R.D.M. 1996. TREEVIEW: an application to display phylogenetic trees on personal computers. Comput. Appl. Biosci. 12:357-358.

Piljac, J., E. Maletic, J.K. Kontic, G.S. Dangl, I. Pejic, N. Mirosevic, and C.P. Meredith. 2002. The parentage of Posip bijeli, a major white wine cultivar of Croatia. Vitis 41:83-87.

Rovira, M. 1997. Genetic variability among hazelnut (C. avellana L.) cultivars. Acta Hort. 445:45-50.
Solar, A., F. Stampar, and V. Usenik. 1997. Identification of some hazelnut cultivars (Corylus avellana L.) with isozyme analysis. Acta Hort. 445:21-29.

Tasias Valls, J. 1975. El Avellano en la Provincia de Tarragona. EXCMA Diputación Provincial de Tarragona, Tarragona, Spain.

Thomas, M.R., S. Matsumoto, P. Cain, and N.S. Scott. 1993. Repetitive DNA of grapevine: classes present and sequences suitable for cultivar identification. Theor. Appl. Genet. 86:173-180.

Thompson, M.M., H.B. Lagerstedt, and S.A. Mehlenbacher. 1996. Hazelnuts, p. 125-184. In: J. Janick and J.N. Moore (eds.) Fruit breeding, Vol. 3, Nuts. Wiley, New York.

Thompson, M.M., P. Romisondo, E. Germain, R. Vidal-Barraquer, and J. Tasias Valls. 1978. An evaluation system for Filberts (Corylus avellana L.). HortScience 13:514-517.

Tous, J. 2005. Hazelnut production in Spain. Acta Hort. 686:659-663.

UPOV. 1979. Guidelines for the conduct of test for distinctness, homogeneity and stability. Hazelnut (Corylus avellana L. \& Corylus maxima Mill.) TG/71/3 [online]. 26 Feb. 2008. <http://www.upov.int/en/publications/ tg-rom/tg_index_numerical.html $>$.

Vouillamoz, J., D. Maigre, and C.P. Meredith. 2003. Microsatellite analysis of ancient alpine grape cultivars: pedigree reconstruction of Vitis vinifera L. 'Cornalin du Valais'. Theor. Appl. Genet. 107:448-454.

Wagner, H.W. and K.M. Sefc. 1999. IDENTITY 1.0 [online]. 26 Feb. 2008. <http://www.boku. ac.at/zag/forsch/identity.htm $>$. 